\title{
Contracting accountability in network governance structures
}

\author{
Lisa Hansson and Frode Longva
}

\section{Linköping University Post Print}

\section{Tweet}

N.B.: When citing this work, cite the original article.

Original Publication:

Lisa Hansson and Frode Longva, Contracting accountability in network governance structures, 2014, Qualitative Research in Accounting \& Management, (11), 2, 92-110.

http://dx.doi.org/10.1108/QRAM-04-2014-0032

Copyright: Emerald

http://www.emeraldinsight.com/

Postprint available at: Linköping University Electronic Press

http://urn.kb.se/resolve?urn=urn:nbn:se:liu:diva-115137 


\section{Article Title Page}

[Article title] Contracting accountability in network governance structures

Author Details (please list these in the order they should appear in the published article)

Author 1 Name: Lisa Hansson

Department: Department of Society, Environment and Transport

University/Institution: the Swedish National Road and Transport Research Institute

Town/City: Linköping

State (US only):

Country: Sweden

Department: Political Science Division, Department of Management and Engineering

University/Institution: Linköping University

Town/City: Linköping

State (US only):

Country: Sweden

Author 2 Name: Frode Longva

Department: Department of Mobility and Organisation

University/Institution: The Institute of Transport Economics

Town/City: Oslo

State (US only):

Country: Norway

Corresponding author: Lisa Hansson

Corresponding Author's Email: lisa.hansson@vti.se; lisa.hansson@liu.se

Please check this box if you do not wish your email address to be published

\section{Acknowledgments (if applicable):}

The research on which this article is based was funded by the Swedish Innovation Agency VINNOVA. VINNOVA is a Swedish state founded research agency; they have had no participation in the research process or the outcome of the results. The authors want to thank project team members Robert Hrejla, Enza Lissandrello, Tomas

Svensson, Tim Richardson, Petter Næss and Aud Tennøy as well as the two anonymous referees for valuable comments on previous versions of the article.

\section{Biographical Details (if applicable):}

[Author 1 bio] Lisa Hansson, Ph.D., holds a research position at the Swedish National Road and Transport Research Institute and has a post doc position in Political Science at Linköping University. Hansson's research concerns regulatory governance and implementation in relation to market reforms.

[Author 2 bio] Frode Longva, Cand. Polt., is Research Director at the Department of Mobility and Organisation at the Norwegian Institute of Transport Economics. Longva has a broad research expertise within the transport sector, in particular questions concerning governance, organisation and regulation.

\section{Structured Abstract:}

\section{Purpose}

The purpose of this paper is to illustrate how accountability is expressed in contractual arrangements found in network governance structures that provide public transport services and to raise discussion of how to understand contracting accountability in network governance contexts.

\section{Design/methodology/approach}

The paper is rooted in two research traditions: contracting studies and studies of accountability in government/governance contexts. Content analysis is used in examining contracts from two cases. These contracts are of five types: contracts between public organizations, contracts within a public organization,

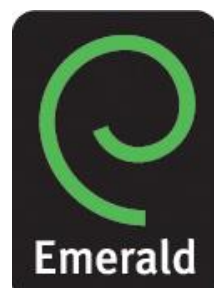

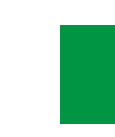

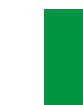


contracts between public organizations and private firms, and contracts between political parties within a municipality and contracts within a network. Various contracting approaches are identified within these types.

\section{Findings}

The paper concludes that the contracts' functions differ between the cases. The first case did not have an overall contract that defined the network, relying on different two-party contracts instead. In the other case, an incentive-based contract was used to link the organizations. From an accountability perspective, the latter contracting structure clarifies the roles and responsibilities of the actors and increases the possibility of accountability to citizens.

\section{Originality/Value}

The paper brings new insights to the field of contracting and accountability by focusing on the role of contracts in network governance structures, taking account of various accountability relationships. It also contributes new theoretical categories usable when analysing contracting accountability in a network context.

Keywords: Accountability, Contracting, Network, Governance, Public Transport

Article Classification: Research paper

For internal production use only

\section{Running Heads:}




\section{INTRODUCTION}

Network governance is a pluralistic concept relating to the various forms of networks: endogenous, emerging from below, or designed from above, formal or informal, intra- or inter-organizational, open or closed, short or long lived, and policy specific or society wide (Sørensen and Torfing, 2009, p. 234). It consists of hierarchical government structures and new structures introduced and shaped by interaction between governmental and nongovernment actors (Sørensen and Torfing, 2009). Providing public services via network governance challenges traditional public administration concepts and values (Wihlborg and Palm, 2008). This paper focuses on one fundamental principle, i.e. accountability, and in specific the accountability mechanism of contracting. Accountability concerns the possibility of holding the actors governing a political action responsible for their actions (Mulgan, 2000). Accountability is crucial in upholding a legitimate democratic political system, as it ensures that public officials will act to meet citizen needs (Romzek and Dubnick, 1998). With the development of network governance, accountability has attracted new attention. In network governance it can no longer be assumed that public authorities possess the kind of authority traditionally ascribed to public organizations, which in turn challenges the possibility of citizens' holding elected officials accountable. Accountability is more intertwined and multiple, as the network governance context includes both old and new competing government structures (Romzek et al., 2012). It has been argued that contractual agreements play an important role in establishing accountability in contexts in which multiple organizations interact (Wihlborg and Palm, 2008). Contracts can be used to specify the obligations of actors involved in a network. From the citizen's perspective, contracts are a mechanism that can make roles transparent and clarify responsibilities, which is fundamental for legitimizing the democratic system (Considine, 2002). However, when using formalized contracts in a network context, the contracts need to be adapted to capture the competing interests in the network.

The paper aims to illustrate how accountability is expressed in contractual arrangements found in network governance structures that provide public transport services and to raise discussion of how to understand contracting accountability in network governance contexts.

Accordingly, several contracting arrangements are studied in relation to each other: contracting between and within public organizations, contracting between public and private organizations, and network contracting. Numerous studies have focused on contracting arrangements between two parties, often public and private organizations (see, e.g., DeHoog, 1990). Such studies demonstrate the difficulty of designing contracts clarifying roles between parties (Greve, 2000; Hart and Holmström, 1987; Romzek and Johnston, 2005). By focusing on public-public, private-public, and network contracting arrangements, the paper brings a new perspective to studies of contracting and accountability, specifically that of ensuring accountability by network contracting, while taking account of multi-party arrangements. Using the Almqvist and Högberg (2005) model, we also supply new theoretical categories 
that complement existing contracting analyses in its application to a network governance context.

\section{CONTRACTS AND ACCOUNTABILITY IN A GOVERNANCE CONTEXT}

The paper is rooted in two research traditions: contracting studies and studies of accountability in government/governance contexts. Accountability is relational, since it involves interaction between two or more parties. Three questions are often used to analytically capture the accountability concept: Who is held accountable, for what and to whom? (Mulgan, 2000). Accountability faces different challenges depending on the steering context (see Table I, adapted from Wihlborg and Palm, 2008, p. 325). A governmental steering context refers to actions taken within a government structure. The questions of who and to whom are clear, since they are defined by the hierarchical structures of government; for example, a politician holds bureaucrats accountable. The question of what, namely, the content of responsibility, is more difficult to define, as bureaucrats handle many tasks in a public organization. The same applies to the accountability relationship between politicians and the electorate: the content is difficult to define as politicians are involved in many policy areas. The use of contracts to define responsibilities has often been a non-issue in government structures, as the tasks are based mainly on trust in performance related to the actor's role in the government structure (Van de Walle, 2013). In governance structures accountability is horizontal and vertical (Romzek et al., 2012). Horizontal accountability is a non-hierarchical form of accountability shaped by relationships with organizations, firms, and stakeholders outside the vertical hierarchal relationship between politicians and bureaucrats (Considine, 2002). The question of who becomes difficult to define, as many actors are involved in the decision making. The use of contracting is more common in governance structures due to the increasing use of tendering, and contracts constitute a mechanism that can define the content and direction of accountability in a particular governance context (Wihlborg and Palm, 2008). Depending on the government/governance context, the challenges differ when it comes to ensuring accountability, making contracting an interesting accountability mechanism.

\section{Table I}

Contracting studies have demonstrated that contracts are influenced by the traditions and values found in the contexts in which they are formulated. Contracts therefore have various features and functions (Camén, 2011). Contracting also includes elements of uncertainty, as it must deal with problems of information asymmetry and moral hazard, and it has proven difficult to formulate contracts that can accommodate such problems (Romzek and Johnston, 2005). A solution reducing the likelihood of implementation problems is to specify in detailed terms the responsibilities, incentives, and monitoring functions (Sappington, 1991). Still, many public sector contracts do not use incentives or prescribe monitoring functions; instead, the contract may serve other functions. It is important to capture the variety of functions a contract can serve. One way is to analyse the design of a contract (Almqvist, 2001; Walsh 
1994). Applying a two-dimensional model of quality criteria (dimension one: general, checkable, and measurable criteria; dimension two: resources, processes, and outcome requirements), Almqvist and Högberg (2005) identify three approaches to contracts among the contracting parties. In the control-based approach, which is similar to that described above, contracts contain a high level of detail, including sanctions and procedures for noncompliance. This approach assumes that contracting parties have divergent interests and that the purpose of a contract is to allocate risks, responsibilities, and rewards. In the trust-based approach, based on the need for trust between contracting parties, the contract symbolizes that the parties are striving for close cooperation. Sanctions are seen as ineffective in this approach; instead, problems are solved when the parties "jointly work out how to attain certain objectives... or how to overcome difficulties" (Almqvist and Högberg, 2005, p. 248f). The contracts are not fully specified; instead, some criteria are dealt with in trust-based ways, such as negotiation between the parties. The last category is the non-contractibility-based approach. It is found in contracting activities in which it is difficult to specify requirements in a way that permits measurement of quality outcomes. Instead, focus is on specifying the processes and resources used to achieve quality. (Almqvist and Högberg, 2005).

To analyse contracting accountability in network governance structures, we have constructed an analytical model based on a combination of the accountability model in Table I and Almqvist and Högberg's (2005) contracting approaches. The model is presented in Table II.

\section{Table II}

Row one in the table states the accountability questions. The second row states the contracting approaches. The accountability questions of "who" and "to whom" focus on relations between two or multiple parties; this meets the contracting aspect of relational contracts. In order to capture "who" and "to whom" we will identify contracting parties found in each contract. "What" will be captured by analysing the design of each contract, using the contracting approaches.

\section{METHOD}

The empirical material concerns two networks providing public transport services. Both cases are multi-level, meaning that public organizations at different government levels are interacting with private organizations to achieve public transport. The first network concerns public transport in Helsingborg, Sweden and the second, public transport in Trondheim, Norway. The cases were selected mainly according to Mill's method of agreement (Weber, 1990), i.e., there is variation in the independent variables between the cases but the outcomes are similar. The case selection was originally based on the design of the research project of which this study part of. However, within those confines, we have chosen cases theoretically suitable for analyzing contracting accountability. The variation refers to the type of network governance structure for public transport. The main difference between the cases is that Helsingborg has the explicit vision of forging a collaborative partnership with evenly distributed power resources. The network is based on a bottom-up initiative of actors in the 
network. The other case, Trondheim, also has elements of collaboration, but includes national government funding and is a response to top-down incentives. Both cases have similar outcomes: they are seen as proactive in their public transport solutions, due to the decisive actions taken to reduce congestion and carbon dioxide emissions by reshaping the transport system. Since this paper is delimited to focus on contracting accountability we will not make claims explaining outcomes related to public transport per see.

Contracts defining relationships between two or more actors in a network constitute our main empirical material. The findings are based on eleven contracts (see Table III). In addition to contracts, interviews and public documents were analysed to obtain a contextual understanding of the networks. Five interviews were conducted in the Swedish case, with officials from the municipality, public transport authority, and a private organization; all respondents are key actors occupying strategic positions in the network. The same applies to the Norwegian case. We have focused on the main contracts currently in force that are relevant when defining the actors connected to the financing, planning, or provision of public bus transport. We defined a contract as a "formal agreement" when determining what constitutes a contract (Camén, 2011); therefore we include agreements that are not necessarily formally termed "contracts" but serve the same purpose. This is arguably a broad definition, but as this paper seeks to analyse the contractual relationships within a network, taking account of public organizations as well, this wider definition was necessary. The selected contracts were subjected to content analysis, using the qualitative elements of the method, focusing on the content of sentences that describe aspects of accountability (Weber, 1990, p. 37). The contracts were analysed in several steps. First we read the contracts to gain an overview of their contents. Then the analytical model described in section 2 was applied. Each case was first analysed separately, and then the cases were analysed comparatively. Content analysis is a method well established and has been used in similar studies of contracting (see, e.g., Dicke and Ott, 1999).

\section{FINDINGS}

\subsection{Introducing the cases and accountability relationships}

Case one concerns Helsingborg, for over 20 years the traffic volume has increased in the inner city of Helsingborg. Road noise problems are serious, streets in the city centre are congested, road accidents have increased in number, and air pollution exceeds permitted limits. Traffic is estimated to be the main contributor to Helsingborg's problems (Helsingborg, 2007). In 2003, Helsingborg Municipality formulated a vision emphasizing greater use of public transport (Reiter, 2003). New financial structures and institutions were suggested: "Cooperation was required within the municipal organization itself, with other municipalities, and within the area of overall county responsibility. Cooperation was also required with private sector players in order to foster innovation" (Helsingborg, 2012). A "partnership organization" was proposed. Helsingborg Municipality and the county public transport authority, Skånetrafiken, agreed on a joint partnership and in 2004 an invitation to tender was posted for public 
transport bus operators. The winning bus operator was to become a full member of the partnership. The private company Arriva won the tender. Since 2005, a partnership has existed between Arriva, Helsingborg Municipality, and Skånetrafiken (Helsingborg, 2012).

Three types of accountability relationships are found in the Swedish case; see Figure 1 for the organizations involved in the network and Table III for clarification of the specific contracts found in the cases. The first type is between two public organizations (number 1 in Figure 1, C1-C3 in Table III). Skåne Regional Council is the self-governing authority of Skåne County and directly elected by the inhabitants of Skåne; it has an agreement with Helsingborg Municipality concerning public health and regional development questions. The public transport authority, Skånetrafiken, is the department in Skåne Regional Council that is responsible for regional public transport. There is a specific contractual agreement between this department and Helsingborg Municipality regarding public transport. The second type concerns accountability relationships within a single public organization (number 2 in Figure 1, C5 and C6 in Table III). In Helsingborg Municipality there is an agreement between the Municipal board and the Department of City Planning, which has operational responsibility for local transport infrastructure. The contract between Skåne Regional Council and Skånetrafiken is also of this type. The third type concerns relationships between a public and a private organization (number 1 in Figure 1, C7 in Table III) In this network, the contract between Skånetrafiken and the operator Arriva is central. Arriva is responsible for providing public transport in the municipality. The core partnership actors, i.e., Skånetrafiken, Helsingborg Municipality, and Arriva, are collectively indicated by the circle in Figure 1. Notably, no single contract creates the partnership by binding together its parties; instead, the arrangement is established via multiple contracts.

\section{Figure 1}

Case two concerns public transport in Trondheim area, Norway. Trondheim is among the areas in Norway with the highest population growth and the road traffic volume has increased rapidly there. Approximately half of Trondheim's $\mathrm{CO}_{2}$ emissions come from road traffic. In response to increasing environmental problems, the Miljøpakken environmental package will be implemented in the Trondheim area. This environmental package is one of the most ambitious investments in urban transport system in Norway. Within 15 years, approximately seven billion dollars will be invested to improve the transport system and along the roads leading to the city. Trondheim Municipality, Sør-Trøndelag County Council, and the National Roads Administration have shared responsibility and are cooperating to improve conditions for more environmentally friendly traffic (Miljøpakken, 2013). The present paper focuses on the public transport-related contracts in the Miljøpakken environmental package and on the regular accountability relationships in public transport implementation.

The first type concerns accountability relationships between three public organizations (number 1 in Figure 2, C4 in Table III). The Ministry of Transport and Communications has a joint agreement with Trondheim Municipality and Sør-Trøndelag County Council regarding the financing of public transport investments in Miljøpakken. The agreement is formulated as 
a public reward scheme in which Trondheim Municipality and Sør-Trøndelag County receive extra state support for introducing public-transport-enhancing measures. This support is granted according to specific goals stated in the agreement, and provides state funding to supplement ordinary framework funding under the county council responsibility. This contract defines accountability relations between public organisations, however it also defines the network (type 5 in Table III). The second type is contracts within a single public organization (number 2 in Figure 2, C10 and C11 in Table III). In Sør-Trøndelag County there are two contractual agreements between the County Council and the public transport authority AtB, a framework contract and a delivery contract. The third type is between a public and a private organization (number 3 in Figure 2, C8 in Table III); consisting of contracts between AtB and bus operators. Three bus operators are responsible for providing public transport in central Trondheim. The fourth type is between the political parties in Trondheim, where the content of the Miljøpakken environmental package is defined. Similar agreements are found in Sør-Trøndelag County Council (number 4 in Figure 2, C9 in Table III).

\section{Figure 2}

There are several differences in the accountability relationships between the two cases. One major difference is that no overall contract binds together the Swedish network, while the Norwegian network has an overall contract that defines the responsibilities in the network as well as a contract binding the political parties in Trondheim to the obligations specified in the overall contract. Both networks include multi-level and intra-organizational contracts.

\section{Table III}

\subsection{Accountability aspects in the contract designs}

This section presents our findings from analysing the selected contracts. The section is subdivided based on the various accountability relationships.

\subsubsection{Contracts between public organizations}

The Swedish contracts between public organizations are written in a goal-oriented way in which mutual obligations are stated. The contracts recall Almqvist and Högberg's (2005) trust-based contracting. The goals are followed by descriptive headings such as "responsibility" and "finance" ([C3]). As some contracts define monitoring tools in the form of evaluations, the measurements are process based. The evaluation is vaguely described and no sanctions are specified. For example, the contractual agreement between Skåne Regional Council and Helsingborg Municipality ([C3]) states "Evaluation is conducted through ongoing consultations between the parties. A deeper evaluation of the results will be conducted after five years" ([C3]). It is not specified how often the "ongoing consultations" will occur or what forms they will take. The agreement between Skåne Regional Council and its municipalities does not have a separate heading for evaluation; instead, evaluation tools are described in various places in the text along with discussions of other matters, such as regional development ([C1]). The contracts often use legal sources to define the 
responsibilities. For example: "The responsibility for local and regional traffic is regulated in the Act on Public Transport [2010, p. 1065] that provides for regional public transport and the reorganization of the regional public transport authority" ([C1]).

The Norwegian contract between the Ministry of Transport and Communications, SørTrøndelag County Authority, and Trondheim Municipality ([C4]) embodies the binding agreement that addresses the main public transport aspects of the Mijøpakken. It is a contract between different public organisations, but it also constitutes the contract of the network. Like the Swedish case, the agreement articulates visionary goals; otherwise the contract differs in several respects from the public-public contracts in Sweden. The Norwegian contract is more precisely written and has many features that recall control-based contracting. The contract defines resources in terms of financial obligations, specifying the support to be given by central government to fund the Trondheim package; the financial figures are presented in a chart and accompanying text. It is followed by a precise specification of responsibilities related to both process and quality outcomes. For example, the percentage of workplaces that should be located near public transport initiatives. Goals that could be politically controversial are also stated in the contract, for example, aspects of how Trondheim should deal with parking ([C4]), a matter otherwise decentralized to the local level. As in the Swedish contracts, references are made to juridical directives. In addition, procedural requirements, such as monitoring, are described. The contract states that "At the end of the four-year period, there should be systematic documentation and evaluation that indicates: the extent to which the assumptions are satisfied and agreed-on actions implemented; the development of traffic and transport in the period; the extent to which specific targets have been met and an explanation of any deviations [from these targets]" ([C4]). The description concerning evaluation is more detailed in the Norwegian than the Swedish contract, but the formulations are in both cases open to interpretation.

\subsubsection{Contracts between political parties}

In the Trondheim network, there is a contractual agreement between the political parties within the municipality defining the package ([C9]). This agreement is related to the environmental transport plan and the contract between the Ministry of Transport and Communications and various Trondheim-region organizations. The basic financial element of this agreement is the use of toll rings, which in Norway is a Parliamentary decision, requiring a broad local political consensus. The political agreement puts the local consensus on paper, enabling the establishment of toll rings as part of the environmental package. The contract also constitutes a vital policy measure enabling supplementary state funding. Accordingly, the agreement between the political parties was prove of political consensus needed for the establishment of toll rings, signalling local support of both a vital policy measure and a financial element even in the event of political change in Trondheim. The contract is similar to the Swedish contracts between public-public organizations in that it is goal oriented, although the Norwegian party contract has more precise outputs. The contract also includes a timeframe and an endpoint ([C9]). The agreement contains overall goals between the parties and often measurable quality outputs related to these goals; for example, "the direct climate 
emissions from transport should be reduced by $40 \%$. The agreement also describes in considerable detail what a restrictive parking policy should entail ([C9]). This type of detailed level of contracts could suggest a control-based contracting approach. However, the agreement does not specify any incentives or monitoring which are central elements in a control-based contracting approach and we can therefore not place the party contract into this category.

\subsubsection{Contracts within a public organization}

In the Swedish network there are contractual agreements that define public-public relationships within a single public organization (type 2). The contract focuses on procedural elements, specifying tasks that the Skåne Regional Council board has delegated to Skånetrafiken; in this, it displays features in line with Almqvist and Högberg's (2005) noncontractibility approach. Similar to the public-public contracts, the within-government contracts cite juridical directives ([C5]). However, these contracts do not articulate goals, financial incentives or time frames for execution.

The Norwegian case includes contracts between units within one public organization, in this case, between the Sør-Trøndelag County Authority and the public transport purchasing body AtB. AtB is $100 \%$ owned by the County Authority but is organized as a public company. This organizational solution differs from that in the Swedish case, in which the purchasing body is a department and not a public company. Two contracts are analysed, one framework contract and one delivery contract [C10, C11]. The framework and the delivery contracts are interrelated, as the delivery contract specifies the obligations referred to in general terms in the framework contract. The framework contract has features that recall the noncontractibility approach, stating the overall goals of public transport and clarifying the parties' responsibilities. This contract also includes obligations to the users of public transport, something not found in other contracts. It also covers procedural aspects; such as yearly evaluation reports [C10]. The delivery contract is more detailed and can be categorized as a control-based contract; Obligations related to quality outputs, procedural aspects (e.g., regarding routes and forms for ticketing and monitoring functions (e.g. types of statistics to be reported) are specified [C11].

\subsubsection{Contracts between public organizations and private organizations}

Both cases have contracts between public organizations and private firms. These contracts are competitive tendering contracts; they include considerable detail and are structured similar to the control-based approach. No mutual goals are set; instead, various tasks are listed that the operator is expected to perform for the public transport authority $([\mathrm{C} 7, \mathrm{C} 8])$. The contracts contains incentives related to quality outcomes; mainly described as financial benefits. It is clearly stated what will happen if the party does not uphold the contract, in which negative incentives are invoked ([C8]). In addition, the tendering contracts state that disputes regarding the terms of the contracts will be settled in court $([\mathrm{C} 7, \mathrm{C} 8])$. 
A main difference between the Helsingborg and Trondheim cases is that in Trondheim several operators are involved in providing public transport. They have an operational function and are only involved in driving the different transport modes. In Helsingborg there is only one operator who should, as was intended in the partnership idea, be a partner in the arrangement. This means that the operator should be included in workgroups and in the decision making for the city's traffic and infrastructure planning (interview A; Reiter, 2012). However, the Swedish tendering contract does not include any terms that encourage broader involvement or participation on the part of the operator ([C7]).

\subsection{Experience from working in the networks}

In this section we report findings regarding work in the networks related to the accountability relationships and the contracts. In the Swedish case, one of the main reasons for creating a partnership was to find innovative ways to reduce congestion in the inner city and to increase public transport use. This would require both new organizational structures and new technology. Evaluations show that goal outcomes are positive regarding congestion and public transport use; for example, the number of public transport journeys has increased by $40 \%$ (Helsingborg, 2012). The new organizational solutions, however, have not lived up to expectations. The partnership was to comprise three types of groups: a political committee, a steering group, and three working groups. Each organization would be included in each group and chair one of the working groups. However, the private bus operator Arriva has not been included in the political committee. The public transport authority Skånetrafiken argues that it is impossible to let a private company play a decision-making role when it comes to public matters (Interview B). There is no equal division of working group leadership, as Skånetrafiken chairs all three working groups. The efforts of the partnership are directed by Skånetrafiken, proposals are often initiated by Skånetrafiken and the other parties are then consulted. The public transport authority uses its expertise and excludes the other parties from work; e.g., Arriva was excluded from marketing campaigns (Reiter, 2012). "We believed there was an obvious risk of conflict if the organization that worked on the proposals differed from the organization that financed them", said a public official at Skånetrafiken to why Arriva was not included in central activities (Interview D, translated). Helsingborg Municipality and Arriva have developed another type of relationship than with Skånetrafiken. The municipality has supported Arriva in several matters, arguing that Arriva should have a more equal role in the partnership (Interview A). The operator confirms its good dialogue with the municipality but also stresses that the municipality has not met its obligations concerning infrastructure, which in turn affects Arriva's ability to provide timely service (Interview C).

Trondheim, Norway, has the same decision-making bodies and political processes as existed before the Miljøpakken was introduced. Those involved are allotted dedicated time to work on the package, some $100 \%$ of full time and others less. Even though they continue to work in their original entities, those involved notice the difference (Interview F, Interview G). The extra financial resources following the agreement have awakened formerly dormant bodies and coordinating working groups: "The working groups were there before, but many of them had not been functioning due to lack of money. Now they are back in operation because of the 
money supply - there is a big difference!” (Interview I, translated). While all policy measures are addressed in working groups and coordinated in the policy package steering committee, land use issues are still left up to the municipality to decide: "Land use is still handled through regular municipal avenues, outside the formal framework of the environmental package. There are also many individual decisions that water down the densification goal formulated in the package" (Interview H, translated). The 2009-2012 funding agreement pinpoints the Miljøpakken goal of a $12 \%$ reduction in urban road traffic volumes between 2008 and 2018, a goal that has already almost been reached. In 2011, public transport use increased by $11 \%$ in Trondheim and $25 \%$ in the surrounding municipalities. However, it has proven difficult to control industrial developments according to the goals set in the agreement, so the number of workplaces located near public transport initiatives is inadequate (Miljøpakken, 2013).

\section{CONCLUDING DISCUSSION}

The aim of the paper has been to illustrate how accountability is expressed in contractual arrangements found in network governance structures and to raise discussion of how to understand contracting accountability in network governance contexts. Based on contracts from two networks, we have analysed the contracts according to Table 2. Four types of accountability relationships were identified: a) between two or several public organizations, b) between two units within a single public organization, c) between public organizations and private firms, and d) between political parties within a municipality. When analysing the content of the contracts, we applied the control-, trust-, and non-contractibility-based contracting approaches (Almqvist and Högberg, 2005). Our first conclusion is that the contracting approaches differ both between and within the networks. E.g. each contract includes at least one type of goal, but the level of detail in which this goal is specified differs greatly. This strengthens the view that contracts are context specific to the type of network analysed.

\subsection{Contracting accountability relating to the analytical model in section 2}

\section{Table IV}

Table IV describes the contracting approaches related to the accountability relationships found in the networks; as shown; we have added a new accountability relationship, namely, the type 5 network relationship. In the Swedish case, it can be concluded that no contract defines the whole network and the four original types of accountability relationships do not capture the Swedish network structure, so a fifth type of accountability relationship was created. The lack of a contract type that constitutes the network accountability relationship was an unexpected finding. From an accountability perspective, one must ask whether the lack of an overall contract affected the actions taken in the Swedish case. Several responsibilities agreed on in the Helsingborg vision have not been realized. The relationship between Arriva and Skånetrafiken is defined by a contract that recalls Almqvist and Högberg's (2005) control-based contracting approach, i.e., a highly detailed contract based on incentives. Only Arriva's responsibilities are defined in a contract and Arriva has so far 
discharged them. However, the relationship between Skånetrafiken and Arriva is problematic. Arriva is not included in arenas they are supposed to access. Helsingborg Municipality and Arriva have developed what can be seen as elements of a trusting relationship, but without a contracting arrangement. They exchange advice and the municipality has supported Arriva when they have been "mistreated". The difference between Arriva's relationships with the municipality and its relationships with Skånetrafiken raises questions related to contract design and trust (see further discussion in section 5.4). It is impossible to evaluate what effect a network contract would have on the relationships between the parties, but we can see that the relationship Arriva has with the public actor subject to the control-based contractual arrangement differs from the one that is not defined by a contracting arrangement.

In the Trondheim case, a contract defines the responsibilities of the public organizations involved in the environmental package. The network comprises public-public actors so the accountability relationship can therefore be categorized as of type 1. However, the publicpublic contracts in Sweden and the network contract in Norway differ greatly. Using Almqvist and Högberg's (2005) categories, the Swedish public-public contracts apply a trustbased approach, focusing on joint overall goals but not including any specifications, quality measurements, or incentives. The Norwegian public-public contract has features that recall a control-based contract. It receives government funding, and this can explain why e.g. incentives are used. Despite its control approach, the contract itself facilitates infrastructural change, since it makes new investments possible. It can also be seen as a driver of new relationships between the network organizations. The actors continue working in their original and separate entities, but the new agreements have awakened formerly dormant bodies and coordinating working groups. It is too soon to say whether the environmental package contract will lead to increased trust between the parties, though the described roles and forms of collaboration required by the contract may be a starting point for this.

Contracts between public departments or within a public organization apply the noncontractibility-based approach. This type of contract has a process focus, defining working structures and, to some extent, the resources that can be used. Incentives, sanctions or monitoring are not described. They are also somewhat similar to trust-based contracts, as their terms are vaguely specified, though the contracts between public departments are clearly formulated from a regulating perspective but not from the perspective of collaboration between the parties. In this sense, such contracts do not supply a trust-building foundation. It can be questioned whether this type of formal agreement in public organizations should be defined as a contract. We believe that these agreements have features similar to those of the contracts Almqivst and Högberg studied; for this reason, this type of formal agreement can arguably also be included in studies of contracting accountability in networks.

The control-based contracting approach is found in the competitive tendering contracts that define the relationships between public and private organizations. Tendering contracts specify obligations, output measures, incentives, and monitoring functions in detail. The main purpose of control-based contracting is to maximize utility for a single party. In the Swedish case, the bus operator Arriva was said to be a full member of the partnership. The use of 
control-based contracting can therefore seem somewhat surprising as the latitude for negotiation is low compare with trust-based contracting. In the Trondheim case, the operators signing contracts with the public transport authority are both private and public; the contracts they sign do not differ despite their different institutional features. It can therefore be concluded that the contracting approach is the same despite their different institutional structures.

\subsection{New contracting categories}

Our study has also identified contracting approaches that can complement the existing approaches of Almqvist and Högberg (2005). We call these accelerating contracting and indirect contracting. Accelerating contracting was found in the party contract in Trondheim. The party contract was jointly formulated by the municipal political parties and was a requirement to obtain central government funding for the environmental package. The contract would not have been formulated if state support was not in the offing: it is a response to a financial incentive to speed up infrastructural projects. In the long term, many of the investments and infrastructural changes being made in Trondheim would probably have been made in any case, but at a much slower pace, though some might have been overshadowed by other more politically pressing issues. The contract was written to ensure that the municipal political parties would not change their minds, no matter who is governing. Hence the formulation of the contract is based on suspicion and has features typical of a control contract. Some of its goals and features also suggest the control-based approach in terms of level of detail within the contract. However, the control-based category does not sufficiently describe this type of contract, since the contract does not include monitoring functions or sanctions. A contracting approach intended to attract financial support in order to speed up projects does not fit the existing contracting approaches; therefore, we propose a new; accelerating contracting. This type can be found in other sectors as well; for example, in the Swedish health care sector, the national government is initiating many projects accompanied by a monetary incentive, to encourage county councils to speed up privatization reforms in the health sector. These projects sometimes require county level agreement that would not have been obtained otherwise.

The indirect contracting approach is found in the Swedish case. As pointed out, no single contract links the actors in the network; instead, the network is constituted by multiple contracting arrangements. We argue that, from a network perspective, there is a need for a new contracting category. Existing categories do not capture the fact that several individual contracts together may function as a replacement of a single contract binding the parties. The closest existing contracting approach would be non-contractibility. However this approach includes a physical contract and it is features within that contract that is "non contractibility". We suggest an indirect contracting type to indicate how various contracts together may constitute the accountability of the network. This category entails new challenges from an accountability perspective, since there is not one contract that is capturing the roles and responsibilities between the network actors. Instead multiple contracts actually define the indirect contracting category. In order to analyse accountability in indirect contracting one 
must first identify several various types of contracts and then identify the roles within each. The category also raises methodological challenges, since one must have knowledge of the network structure, the contracts existing within the network, as well as access to the contracts.

\subsection{Citizen and contracting accountability in network governance structures}

The citizen is not a visible actor in the empirical material. We have identified only one contract, the framework agreement between the Sør-Trøndelag County Authority and the public transport authority AtB [C10], that discusses citizens, and this is in terms of a dialogue to be held with users. Otherwise, it is difficult to find contractual material that encourages interactions with citizens. It can be concluded that formalized channels for accountability to citizens are not contracted, and that citizens constitute an actor group that receives little attention in written contracts.

From an accountability perspective, a contract that defines roles and responsibilities can be beneficial since it facilitates answering questions related to who, what, and to whom. From the citizens' perspective, it is difficult to answer accountability questions in the Swedish network, since no contract defines the roles. Transparency for citizens is much more likely in the Norwegian case, because a contract exists that defines the responsibilities within the network. The party contract can also be seen as an accountability mechanism for the citizens and other organizations in the network. It clarifies the political direction regarding transport questions in Trondheim, making it clear who should be held accountable for political actions. Hence, despite been created based on distrust, it also provides clarity from an accountability perspective. However, the monitoring functions are lacking which reduces some of the accountability possibilities compare with the network contract.

\subsection{Contacting accountability in network governance - questions for the future}

A central purpose this paper has been to analyse contracting accountability in network governance contexts. An underlying discussion related to this is whether a contract can actually increase or decrease the possibility of accountability. In governance context with the increasing use of contracting, critique is rising that contracts in the public sector is leading to "mistrust that fosters more distrust" (Van de Walle, 2013). Others argue that contracts can play an important role in accountability by defining and clarifying roles and responsibilities within a network (Romzek et al., 2012). Then again, it has been argued that trust is now reentering in the public sector as new collaborative networks and trust-based steering are replacing control systems. Contracting studies emphasize trust as a means to reduce transaction costs and increase contractual flexibility. Trust is seen as something positive and it is claimed that a detailed contract can reduce the possibility that a trusting relationship will arise (Girth, 2012). In our paper, we have analysed both what was on paper a "collaborative network" (the Swedish case) and a network that includes a funding incentive (the Norway case). It is clear in the Swedish case that the organizations in the network know what to do and who should do it despite the lack of an overall contract. However, from a citizens' accountability perspective, it is problematic to answer questions related to who, what, and to 
whom since no contract exists that defines the responsibilities or forms of monitoring. The Norwegian case is shaped by a contract, making the overall situation clearer. Such type of contracting would in the long run foster a more "mistrusting" governance structure.

This analysis serves as a first step for further research. Comparing accountability mechanisms across countries might render more precisely which factors affect policy-making and legitimacy in political systems. It can be assumed that those factors differ both between institutional settings and policy domains. While some policy fields are likely to depend on the accountability mechanisms of bureaucracy, others are likely to rely on external policy actors involving a complex set of contractual arrangements. In theoretical terms, including contracting elements into political science research provides a sharp tool to explain the role of governance structures in policy fields and issues of accountability. In other words: Political scientists and contractual analysts know a lot on varying institutional effects as well as on varying modes of contractual arrangements within policy fields. However, how these two (causally) interact remains a rather unexplored terrain so far. In this paper we have provided a theoretical model of how these fields can complement each other and how contracting accountability can be analysed. We have further developed Almqvist and Högberg's contracting approaches by applying them to a network governance context and identified two new categories. The categories are mainly seen as analytical tools and can be further refined and developed when testing them in new network studies.

\section{REFERENCES}

Almqvist, R. (2001), "Management by Contract": A Study of Programmatic and Technological Aspects, Public Administration, Vol. 79, No. 3, pp. 689-706.

Almqvist, R. and Högberg, O. (2005) "Public-Private partnerships in social services: the example of the City of Stockholm". In C. Greve and G. Hodge (eds) The Challenge of PublicPrivate Partnerships: learning from international experience, Edward Elgar Publishing Ltd, MA.

Camén, C. (2011), Using contracts to manage services: a study of contracts in public transport, Karlstads universitet, Karlstad.

Considine, M. (2002), The edge of line? Accountable governance in the Age of Networks, Partnership and Joined-Up Services, Governance, Vol. 15, No. 1, pp. 21-40.

DeHoog, R. (1990), Competition, negotiation, or cooperation: Three models for service contracting, Administration \& Society, Vol. 22, pp. 317-340.

Dicke, L. and Ott, S. (1999), Public Agency Accountability in Human Services Contracting. Public Productivity \& Management Review, Vol. 22, No. 4, pp. 502-516. 
Girth, A. (2012), A Closer Look at Contract Accountability: Exploring the Determinants of Sanctions, Journal of Public Administration Research and Theory, published online October 11,2012

Greve, C. (2000), Exploring contracts as reinvented institutions in the Danish public sector, Public Administration, Vol. 78, No. 1, pp. 153-164.

Hart, O. and Holmstöm, B. (1987), The theory of Contracts. University Press, Cambridge.

Helsingborg (2007), Trafikplan för staden. Ny syn på trafiken i morgondagens Helsingborg.

Helsingborg (2012), Ökad kollektivtrafik ska skapa Sveriges vackraste gator, available at www.bussvisionenhelsingborg.se (accessed 21 January 2013)

Miljøpakken (2013), Information received from their web-page www.miljopakken.no (accessed 11 January 2013)

Mulgan, R. (2000), “Accountability”: An Ever-Expanding Concept? Public Administration, Vol. 78, No. 3, pp. 555-573.

Reiter, O. (2003), Sveriges vackraste gator. Prioriterad kollektivtrafik i Helsingborgs stadskärna, September 2003.

Reiter, O. (2012), Utvärdering av "Bussvisionen" i Helsingborg, Arbetsmaterial, April 2012.

Romzek, B. and Dubnick, M.J. (1998), "Accountability", in Shafritz, J. M. (Ed.), International encyclopedia of public policy and administration, Vol. 1, A-C. Boulder, Westview.

Romzek, B. and Johnston, J. (2005), State Social Services Contracting: Exploring the Determinants of Effective Contract Accountability, Public Administration Review, Vol. 65, No. 4, pp. 436-449.

Romzek, B., LeRoux, K. and Blackmar, J.M. (2012), A Preliminary Theory of Informal Accountability among Network Organizational Actors, Public Administration Review, Vol. 72, No. 3, pp. 442-453.

Sappington, D. E. M. (1991), Incentives in principal-agent relationships, The Journal of Economic Perspectives, Vol. 5, No. 2, pp. 45-66.

Sørensen, E. and Torfing, J. (2009) Making Governance Networks Effective and Democratic through Metagovernance. Public Administration, Vol. 87, pp. 234-58.

Van de Walle, S. (2013), "NPM: Restoring the Public Trust through Creating Distrust", in Christensen, T., and Laegreid, P., The Ashgate Research Companion to New Public Management, Ashgate, Aldershot, pp. 309-320.

Walsh, K. (1995) Public Services and Market Mechanisms: Competition, Contracting and the New Public Management, MacMillan Press Ltd, NY. 
Weber, R. P. (1990), Basic Content Analysis, 2nd ed. Sage Publications, Newbury Park, CA.

Wihlborg, E., and Palm, J. (2008), Who is governing what? Governing local technical systems: an issue of accountability, Local Government Studies, Vol. 34, No. 3, pp. 349-362.

\section{Interviews}

Interview A, Civil servant, Helsingborg Municipality, 2011-11-02

Interview B, Civil servant, Helsingborg Municipality, 2011-11-02, 2011-11-04

Interview C, Civil servant, Helsingborg Municipality, 2011-11-02

Interview D, Civil servant, Public Transport Authority Skånetrafiken, 2011-11-04

Interview E, Manager at Arriva, 2011-11-03

Interview F, Civil servant, Trondheim Municipality, 2010-06-23 and 2011-06-08

Interview G, Civil servant, Trondheim Municipality, 2010-06-23

Interview H, Civil servant, Trondheim Municipality, 2011-06-07

Interview I, Civil servant, County council, Sør-Trøndelag, 2011-06-07

Interview J, Civil servant, Public Transport Authority AtB, 2011-06-08 
Table I. A modified version of Wihlborg and Palm's (2008, p. 325) model of governance and accountability in two steering contexts

\begin{tabular}{|c|c|c|c|}
\hline Accountability & Government context & & Governance context \\
\hline Who? & $\begin{array}{l}\text { Clarified by hierarchical } \\
\text { structures }\end{array}$ & $\rightarrow$ & $\begin{array}{l}\text { Not clarified due to the } \\
\text { involvement of many actors }\end{array}$ \\
\hline What? & $\begin{array}{l}\text { Not usually specified, as } \\
\text { almost everything is seen as an } \\
\text { obligation for the } \\
\text { governmental body }\end{array}$ & $\rightarrow$ & $\begin{array}{l}\text { Specified, through contracts } \\
\text { based on negotiations and } \\
\text { agreements }\end{array}$ \\
\hline \multirow[t]{2}{*}{ To whom? } & $\begin{array}{l}\text { Bureaucrats to the political } \\
\text { level }\end{array}$ & $\rightarrow$ & Among the contract parties \\
\hline & Politicians to the electorate & & \\
\hline
\end{tabular}

Table II. Model for analysing contracting accountability

\begin{tabular}{|l|l|l|}
\hline Accountability dimension & The questions of who and whom & The question of what \\
\hline \multicolumn{3}{|c|}{$\downarrow$} \\
\hline Contracting dimension & $\begin{array}{l}\text { Contracting parties in the } \\
\text { network }\end{array}$ & $\begin{array}{l}\text { Contract type: control, trust, or non- } \\
\text { contractibility based }\end{array}$ \\
\hline
\end{tabular}


Figure 1. Accountability relationships concerning public transport improvements in Helsingborg, Sweden

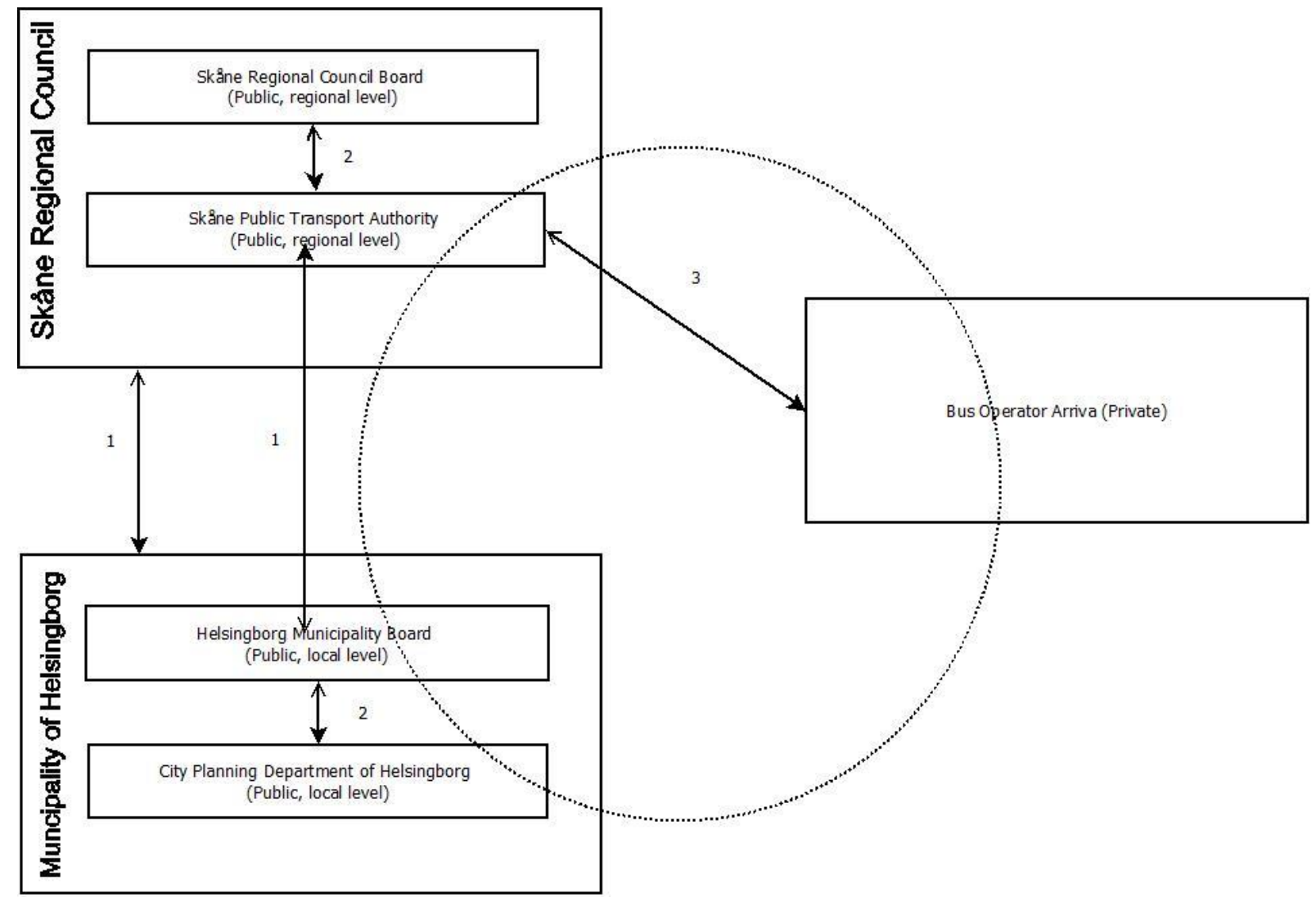


Figure 2. Accountability relationships concerning public transport improvements in Trondheim, Norway

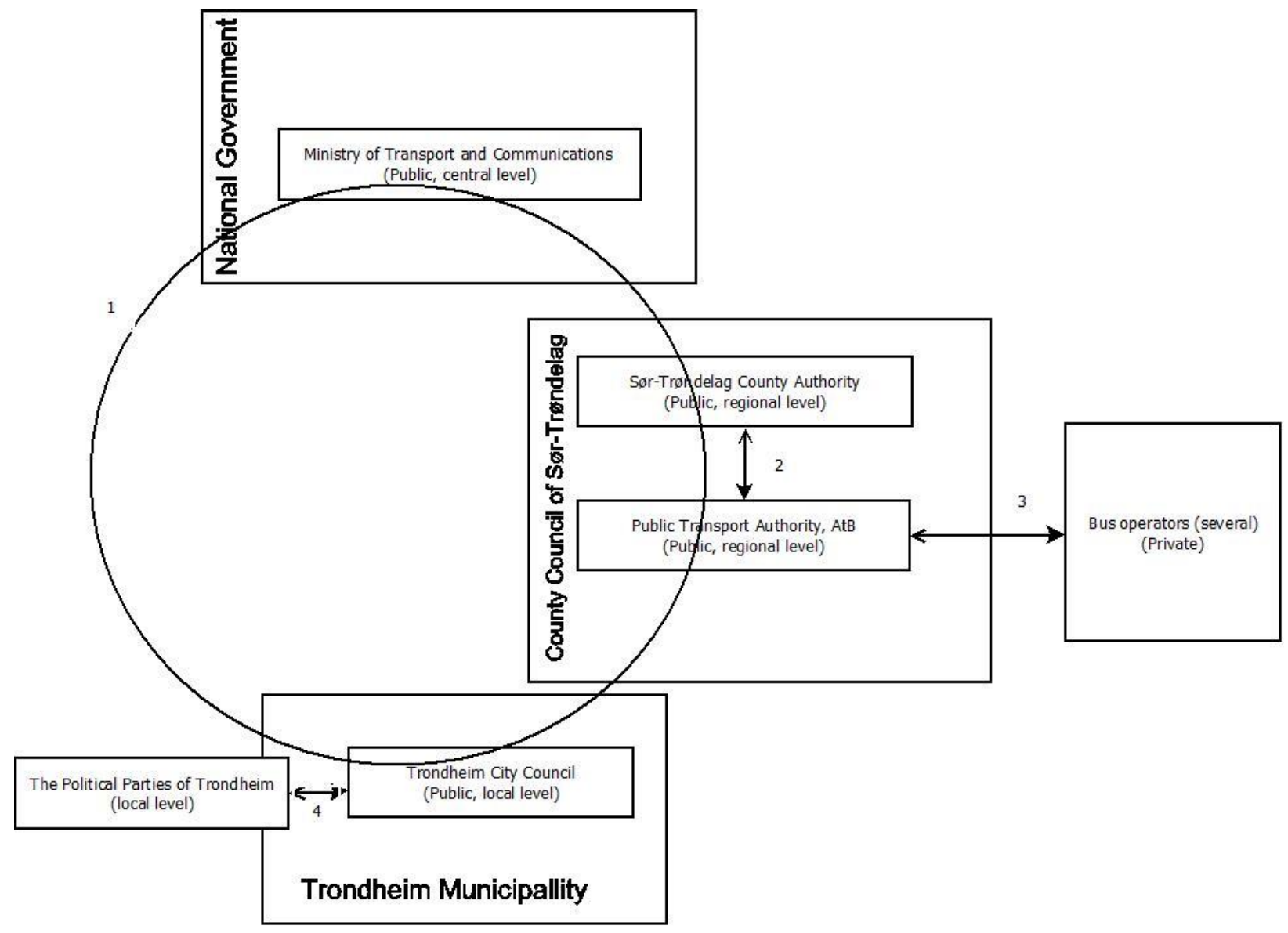


Table III. Accountability relationships and contracts in the cases

\begin{tabular}{|c|c|c|}
\hline $\begin{array}{l}\text { Accountability } \\
\text { relationship }\end{array}$ & Contract & English clarification \\
\hline $\begin{array}{l}\text { Public } \\
\text { organization- } \\
\text { public } \\
\text { organization } \\
\text { (type 1) }\end{array}$ & $\begin{array}{l}\text { Avtal om ansvar för lokal och regional } \\
\text { kollektivtrafik i Skåne. 11 September } 1998 \\
\text { [C1] } \\
\text { Justeringar i avtal om ansvar för lokal och } \\
\text { regional kollektivtrafik i Skåne. } 7 \text { April } 2011 \\
\text { [C2] } \\
\text { Avsiktsförklaring mellan Helsingborg Stad } \\
\text { och Region Skåne/Kollektivtrafiknämnen } \\
\text { angående vision och samarbetsformer för } \\
\text { stadstrafiken i Helsingborg. 2004-05-26 [C3] } \\
\text { Avtale mellom Samferdselsdepartementet og } \\
\text { Trondheimsregionen v/Sør-Trøndelag } \\
\text { fylkeskommune og Trondheim kommune om } \\
\text { belønningstilskudd till bedre } \\
\text { kollektivtransport og mindre bilbruk 2009- } \\
\text { 2012 [C4] }\end{array}$ & $\begin{array}{l}\text { Contract regarding local and regional public } \\
\text { transport in the County of Skane [C1] } \\
\text { Adjustment of the contract regarding local } \\
\text { and regional public transport [C2] } \\
\text { Letter of intent between the municipality of } \\
\text { Helsingborg and the Skåne Regional } \\
\text { Council/Public Transport Board regarding } \\
\text { cooperation and visions of local public } \\
\text { transport in Helsingborg [C3] } \\
\text { Contract between the Ministry of Transport } \\
\text { and Communications, Sør-Trøndelag } \\
\text { County Authority, and Trondheim } \\
\text { Municipality regarding funds for better } \\
\text { public transport and less care use. [C4] }\end{array}$ \\
\hline $\begin{array}{l}\text { Two units in the } \\
\text { same } \\
\text { organization } \\
\text { (type 2) }\end{array}$ & $\begin{array}{l}\text { Helsingborg stad. Reglemente för } \\
\text { Stadsbyggnadsnämnden. Antaget av } \\
\text { kommunfullmäktige den } 14 \text { december 2010, § } \\
\text { 193, rev. den } 14 \text { december } 211, \S 169 \text { [C5] } \\
\text { Region Skåne. Reglemente för regionstyrelse, } \\
\text { nämnder och revisorerna i Region Skåne. } \\
\text { Regionfullmäktige december 2010. Ändringar } \\
\text { gjorda efter beslut 2011-03-01, § } 12 \text { och 2012- } \\
\text { 02-28, § } 10 \text { [C6] } \\
\text { Rammeavtale mellom Sør-Trøndelag } \\
\text { fylkeskommune og Trøndelag kollektivtrafikk } \\
\text { AS. 2009-15-12. [C10] } \\
\text { Leveranseavtale for 2012 mellom Sør- } \\
\text { Trøndelag fylkeskommune og AtB AS. [C11] }\end{array}$ & $\begin{array}{l}\text { Framework agreement between the Sør- } \\
\text { Trøndelag County Authority and the public } \\
\text { transport authority [C10] } \\
\text { Delivery agreement for } 2012 \text { between Sør- } \\
\text { Trøndelag County Authority and the public } \\
\text { transport authority AtB AS [C11] }\end{array}$ \\
\hline $\begin{array}{l}\text { Public } \\
\text { organization- } \\
\text { private } \\
\text { organization } \\
\text { (type 3) }\end{array}$ & $\begin{array}{l}\text { Skånetrafiken. Kontrakt nr 80/2004 } 066 \\
\text { avseende Stadstrafik inom Trafikpaketet } \\
\text { Helsinborg. 2004-06-03 [C7] } \\
\text { Kontrakt for Rutnettet i Trondheim, Klaebu, } \\
\text { Malvik og Melhus mellom Atb AS og Operat } \varnothing \\
\text { [C8] }\end{array}$ & $\begin{array}{l}\text { The public transport authority } \\
\text { Skånetrafiken. Contract regarding public } \\
\text { transport in Helsingborg Municipality. } \\
\text { Competitive tendering contract [C7] } \\
\text { Contract for public transport traffic in } \\
\text { Trondheim Municipality, Klaebu, Malvik, } \\
\text { and Melhus between the public transport } \\
\text { authority Atb and the bus operator. } \\
\text { Competitive tendering contract (several } \\
\text { contracts, one for each operator) [C8] }\end{array}$ \\
\hline $\begin{array}{l}\text { Political parties } \\
\text { in the same } \\
\text { municipality } \\
\text { (type 4) }\end{array}$ & $\begin{array}{l}\text { Trondheim kommunes miljøpakke for } \\
\text { transport - et forlik mellom } 6 \text { partier i } \\
\text { Trondheim bystyre [C9] }\end{array}$ & $\begin{array}{l}\text { Trondheim Municipality environmental } \\
\text { package for transport: an agreement } \\
\text { between six political parties in Trondheim } \\
\text { City Council [C9] }\end{array}$ \\
\hline $\begin{array}{l}\text { Network (type } \\
\text { 5) }\end{array}$ & Swedish case: no contract exist & $\begin{array}{l}\text { Contract between the Ministry of Transport } \\
\text { and Communications, Sør-Trøndelag }\end{array}$ \\
\hline
\end{tabular}




\begin{tabular}{|l|l|l|}
\hline & $\begin{array}{l}\text { Norwegian case: contract C4, also included in } \\
\text { type } 1\end{array}$ & $\begin{array}{l}\text { County Authority, and Trondheim } \\
\text { Municipality regarding funds for better } \\
\text { public transport and less care use. [C4] }\end{array}$ \\
\hline
\end{tabular}

Table IV. Contracting accountability applied to public transport governance networks

\begin{tabular}{|l|l|l|}
\hline \multicolumn{1}{|c|}{$\begin{array}{c}\text { Accountability relationship (who, } \\
\text { whom) / what (contract type) }\end{array}$} & \multicolumn{1}{|c|}{ Helsingborg, Sweden } & \multicolumn{1}{c|}{ Trondheim, Norway } \\
\hline $\begin{array}{l}\text { Public organization-public organization } \\
\text { group 1) }\end{array}$ & Trust based & $\begin{array}{l}\text { Control based; see also the } \\
\text { accountability relationship } \\
\text { Network (group 5) }\end{array}$ \\
\hline $\begin{array}{l}\text { Two units within the same organization } \\
\text { group 2) }\end{array}$ & Non-contractibility based & Non-contractibility \\
\hline $\begin{array}{l}\text { Public organization-private organization } \\
\text { group 3) }\end{array}$ & Control based & Control based \\
\hline $\begin{array}{l}\text { Political parties within the same } \\
\text { municipality (group 4) }\end{array}$ & & Accelerating contract based \\
\hline Network (group 5) & Indirect contract based & Control based \\
\hline
\end{tabular}

